\title{
Comparative Study of Hemispherical Solar Still Using Different Novel Basin Materials With and Without Internal Reflector: Yield, Energy, Exergy, Water Quality and Cost Analysis
}

\author{
Mohammed El Hadi Attia \\ Universite d'El Oued \\ Ahmed Kadhim Hussein \\ University of Babylon \\ Prabha Ramadoss \\ Sri Sairam Institute of Technology
}

Sivakumar Vaithilingam ( $\sim$ vsivakumarascpmech@gmail.com )

Ramco Institute of Technology

\section{Asif Afzal}

PA College of Engineering

Obai Younis

Prince Sattam bin Abdulaziz University

\section{Research Article}

Keywords: Solar Energy, Hemispherical Solar Still, saline waste water, Internal Reflector, basin materials

Posted Date: November 19th, 2021

DOI: https://doi.org/10.21203/rs.3.rs-1036584/v1

License: (c) (i) This work is licensed under a Creative Commons Attribution 4.0 International License.

Read Full License 


\section{Abstract}

The present work deals with the experimental investigation of Hemispherical Solar Still (HSS) using different basin materials with and without Internal Reflector (IR). Three solar stills such us HSS with Steel Basin (HSS-SB), HSS with Zinc Basin (HSS-ZB), HSS with Copper Basin (HSS-CB) was fabricated. Experiments was conducted with and without IR. It was found that, the productivity of the HSS-CB (4.99 $\mathrm{kg} / \mathrm{m}^{2} /$ day) was better than HSS-ZB $\left(4.26 \mathrm{~kg} / \mathrm{m}^{2} /\right.$ day) and both of them were better than HSS-SB (3.64 $\mathrm{kg} / \mathrm{m}^{2} /$ day). Also, It was found that the productivity of the HSS-CB\&IR $\left(5.67 \mathrm{~kg} / \mathrm{m}^{2} /\right.$ day) was better than HSS-ZB\&IR $\left(5.04 \mathrm{~kg} / \mathrm{m}^{2} /\right.$ day), and both of them were better than the HSS-SB\&IR $\left(4.28 \mathrm{~kg} / \mathrm{m}^{2} /\right.$ day). The results revealed that use of IR improves the yield of HSS from 12 to $15.6 \%$. Also thermal and exergy efficiency of the HSS was improved by 14.4 to $20 \%$ and 21.1 to $25.4 \%$ using IR than the without IR. Furthermore, recovery period and water quality analysis has been carried out. The recovery period of HSSSB, HSS-ZB, HSS-CB, HSS-SB\&IR, HSS-ZB\&IR and HSS-CB\&IR are 43, 38, 33, 36, 32 and 29 days, respectively.

\section{Introduction}

Water is the basis of the life on the earth planet, and it is very necessary for durability of the human life on it. One of the biggest challenges encountered the human civilization was who can offer a healthy and fresh water in a reasonable cost especially in the third world countries (Hussein 2015; Rostami et al. 2020). In fact, the natural sources of the fresh water are decrease gradually day by day due to many causes such as effluence of river water by the factories waste, huge population growth, and climate change (Hussein et al. 2016). It is useful to mention that the freshwater quantity was about (1\%), while the other available water (about 97\%) in the ocean is salty and cannot be used for animals, planets and the human demand. The remaining water sources $(2 \%)$ can be found in the north and south Polar Regions as an iceberg (Benabderrahmane et al. 2020). For all these reasons, the SS can be used efficiently to covert the brackish water to a fresh water by using free solar energy. The device which was used to manage this process is called the SS and the principle of its work depends on the famous physical evaporation- condensation concept (Ghodbane et al. 2021). The comprehensive details about the characterization and types of the SS was reviewed by Kabeel and El-Agouz 2011, Hussein et al. 2020, Chauhan et al. 2021, Alnaimat et al. 2021 and Jobrane et al. 2021. The conventional single or double slope SS produced low productivity due to shadow effect occurs by the basin walls. This leads to reduce the solar radiation absorption and decreases its efficiency (Taheri and Zahedi 2020). To get a solution to the above-mentioned drawbacks of the SS and enhances the SS productivity, many researchers are suggested several unconventional designs like regenerative (Sakthivel et al. 2010), air bubbled (Pandey 1984), stepped (Omara et al. 2014), wick (Minasian, A. and Al-Karaghouli 1994), V-type (Kumar et al. 2008), thermoelectric (Rahbar and Esfahani 2012), masonic (Navale et al. 2016), tubular (Rahbar et al. 2015), pyramid (Al-Madhhachi and Smaisim 2021), trays (Essa et al. 2021), hybrid (Mandi et al. 2021) and hemispherical (Ismail 2009) SS. In the latter design of SS, the cover has a hemispherical shape in order to increase the amount of the solar energy collected by the SS by reducing the shadow of still walls. 
In hemispherical design, both the efficiency and productivity are inversely proportional with the depth of water. In spite of the large number of published papers related with different designs of SS, the number of works related with the HSS are very limited up to date. Ismail [23] designed, fabricated and experimentally tested a transportable HSS under climate conditions of Dhahran city (KSA). The SS consisted from a hemispherical cover, distillate collector of a conical shape, mobile support structure, absorber plate, fresh water container and a circular basin. It was deduced that, the SS was able to convert around $50 \%$ of the saline water to a fresh water and its daily efficiency was about $33 \%$. Also, he concluded that this efficiency was decreased with increasing the water depth. (Arunkumar et al. 2012) researched HSS under the weather conditions of Coimbatore (India). Two cases were considered, in the first case, the water flowing to cool the HSS cover. While, in another case this flowing was not considered. They concluded that, the HSS efficiency was increased from 34 to $42 \%$ by adopting the cooling of its cover. The experimental study of the HSS with and without PCM was carried out by (Arunkumar et al. 2013). The SS was integrated with a concentrator, whereas the paraffin wax contained in a black painted copper balls were placed in the basin. The temperatures of PCM, air, water and inner and outer covers of the SS were measured. They found that the SS productivity was increased by about $26 \%$ by using PCM. (Raju et al. 2017) investigated HSS by coupling it with evacuated tubes, paraboloid concentrator and heat pipes under outdoor conditions of Bangalore city (India). The experimental investigation of the performance of a cylindrical SS with a hemispherical dome (CSSHD) was carried out in Najaf city (Iraq) by (Khadim et al. 2021). The cylinder height was varied as 5,15 and $20 \mathrm{~cm}$. It was found that, both the thermal efficiency and yield amount were increased with increasing the cylinder height until it reached respectively $23.3 \%$ and $7.25 \mathrm{~L} / \mathrm{m}^{2}$.day) compared with $\left(15 \%\right.$ and $4 \mathrm{~L} / \mathrm{m}^{2}$.day) for single slope SS. Moreover, they suggested that (CSSHD) was more efficient in winter compared with summer. (Attia et al. 2021) reported the HSS with an iron-fins installed at its basin. The optimum number and length of these fins which are necessary to reduce the shadow effect were studied. They tested three different designs of the HSS under outdoors conditions of El-Oued city (Algeria). The first one was a conventional type without fins, whereas the second and the third types included respectively fins group at $(5 \mathrm{~cm})$ and $(7 \mathrm{~cm})$ distance between each fins. The fin length was varied as 3, 2 and $1 \mathrm{~cm}$ starting from the absorber plate of the basin, while its diameter was fixed at $1.2 \mathrm{~cm}$. It was found that, the yield of the SS was increased up to $56.73 \%$ when the third design was utilized and the fin length was taken as $2 \mathrm{~cm}$. The experimental investigation of the HSS by using respectively black metal trays of iron, zinc and copper in the bottom of their basins was performed by (Attia et al. 2021) under the climate conditions of El-Oued city (Algeria). It was observed that, the improvement in the productivity was increased by about (53.125\%) when the copper trays used compared with the same SS without it. Also, they concluded that using of copper trays increased respectively the yield and thermal efficiency of the SS to their highest value $\left(7.35 \mathrm{~kg} / \mathrm{m}^{2} /\right.$ day and $\left.57.2 \%\right)$ compared with $\left(4.8 \mathrm{~kg} / \mathrm{m}^{2} /\right.$ day and $\left.37.4 \%\right)$ without using any trays.

(Attia et al. 2021) examined experimentally the possibility of using aluminum foil sheet as an absorber cover to increase the yield of the greenhouse SS and compared it with a similar traditional SS which had an absorber of a black surface under the same outdoors conditions of El-Oued city (Algeria). They deduced that, the output of the modified still remain poor $\left(1.004 \mathrm{~kg} / \mathrm{m}^{2} /\right.$ day $)$ and an extra modification 
need to be adopted. Based on the previous literature review, our deep experience in the solar energy and since there is a lack of the fresh water in most of the southeastern regions in Algeria such as El-Oued city (region of study) where a high population live there. Therefore, the major purpose of the present work is to investigate experimentally for the first time the effect of the reflective aluminum foil sheets on the performance of the HSS with various basin materials.

\section{Experimental Work}

\subsection{Experimental setup and description}

The present manuscript aims the experimental investigation of the reflective aluminum foil sheets effect on the performance of HSS with various basin materials. This was achieved by comparing the use of a reflective aluminum foil sheets by placing them on the inner surfaces of the HSS with various basin materials (Steel, Zinc and Copper). To realize this idea, two different experiments were carried out in the present work. In the first day, experiments was conducted on HSS-SB, HSS-ZB and HSS-CB without IR, as shown in Figure 1. In the second experiment three modified HSS were used and their walls were covered by the aluminum foil sheets. In the second day, experiments was conducted on HSS-SB\&IR, HSS-ZB\&IR and HSS-CB\&IR, as shown in Figure 2. The HSS was designed, fabricated and experimentally tested. The HSS consists of a transparent hemispherical cover of $40 \mathrm{~cm}$ in diameter, distillate collector and a circular basin $38 \mathrm{~cm}$ in diameter and $4 \mathrm{~cm}$ in height. The depth of basin saline waste water for each HSS was taken constant at $1 \mathrm{~cm}$. These experiments were conducted in El Oued city (latitude of $33.3676^{\circ} \mathrm{N}$ and a longitude of $6.8516^{\circ} \mathrm{E}$ ) under Algerian weather conditions. Aluminum foil sheet has a shiny side and a matte side. The reflectivity of bright aluminum foil is $88 \%$. The thickness of aluminum foil sheet is about $0.2 \mathrm{~mm}$. Figure 3 shows the photographic view of experimental test rig.

\subsection{Measurements}

The range, uncertainty, and errors values for the experimental data's are presented in Table 1.

Table 1

Standard uncertainties and errors for measuring instrumentation

\begin{tabular}{|llll|}
\hline Instrument & Accuracy & Range & Standard uncertainty \\
\hline Solar power meter & $\pm 10 \mathrm{~W} / \mathrm{m}^{2}$ & $0-1999 \mathrm{~W} / \mathrm{m}^{2}$ & $5.78 \mathrm{~W} / \mathrm{m}^{2}$ \\
\hline Thermocouple & $\pm 0.1^{\circ} \mathrm{C}$ & $-100-500^{\circ} \mathrm{C}$ & $0.08^{\circ} \mathrm{C}$ \\
\hline Graduated cylinder & $\pm 1 \mathrm{ml}$ & $0-500 \mathrm{ml}$ & $0.5 \mathrm{ml}$ \\
\hline
\end{tabular}

\section{Results And Discussions}




\subsection{Time-wise variant of solar intensity $[I(t)]$ and atmosphere temperature $(\mathrm{Ta})$}

Figure 4 display the time-wise variant of $\mathrm{I}(\mathrm{t})$ and Ta for the experimental day 1 and day 2 . From graph 4 , it is identified that $\mathrm{I}(\mathrm{t})$ increase linearly in the morning and reached maximum of $1040 \mathrm{~W} / \mathrm{m}^{2}$ at midday on 14-8-2020 and $1020 \mathrm{~W} / \mathrm{m}^{2}$ at midday on 15-8-2020. Similarly, Ta increases in the morning and reached maximum of $50^{\circ} \mathrm{C}$ at $15: 00$ on $14-8-2020$ and $51^{\circ} \mathrm{C}$ at $15: 00$ on $15-8-2020$. The daily mean I(t) on 14-82020 is $671.54 \mathrm{~W} / \mathrm{m}^{2}$, and on $15-8-2020$ is $663.46 \mathrm{~W} / \mathrm{m}^{2}$ and the daily mean Ta on $14-8-2020$ is $42^{\circ} \mathrm{C}$ and on $15-8-2020$ is $41.46^{\circ} \mathrm{C}$.

\subsection{Time-wise variant of saline waste water temperature (Ts.w)}

Figure 6 Time-wise variant of Ts.w for the HSS-SB\&IR, HSS-ZB\&IR and HSS-CB\&IR

3.3 Variation of Evaporative Heat Transfer Coefficient (EHTC) and yield production per hour from the HSS-SB, HSS-ZB, HSS-CB, HSS-SB\&IR, HSS-ZB\&IR and HSS-CB\&IR

Figure 7 displays the time-wise difference of EHTC and hourly yield production from the HSS-SB, HSS-ZB and HSS-CB on 14-8-2020. The highest calculated EHTC of the HSS-SB, HSS-ZB and HSS-CB are 40.09, 43.46 and $45.25 \mathrm{~W} / \mathrm{m}^{2} \mathrm{~K}$ on $14-8-2020$. The everyday average EHTC of $21.49,23.44$ and $24.82 \mathrm{~W} / \mathrm{m}^{2} \mathrm{~K}$ is calculated for the HSS-SB, HSS-ZB and HSS-CB, respectively. The everyday average EHTC of the HSS-CB is greater than the HSS-SB, HSS-ZB due to the greater thermal conductivity value of copper basin. The everyday mean EHTC value of the HSS-ZB and HSS-CB is $9.04 \%$ and $15.49 \%$ greater than the everyday mean EHTC of the HSS-SB and every day mean EHTC value of the HSS-CB is $5.9 \%$ greater than the everyday mean EHTC value of the HSS-ZB. In HSS-CB, copper material improves the Ts.w and so it has greater hourly and everyday EHTC than the HSS-ZB and HSS-SB. From figure 5, it is found that yield production from the HSS-SB, HSS-ZB and HSS-CB are increasing in the before noon and decreases in afternoon. The highest yield of $0.71,0.81$ and $0.94 \mathrm{~kg}$ was produced from the HSS-SB, HSS-ZB and HSS$\mathrm{CB}$, respectively. The everyday yield production from the HSS-SB is $3.64 \mathrm{~kg}$, from the HSS-ZB is $4.26 \mathrm{~kg}$ and from the HSS-CB is $4.9 \mathrm{~kg}$ on 14-8-2020. While using the copper basin in the HSS, yield was augmented by about $37.23 \%$ and $17.22 \%$ related to the HSS-SB, HSS-ZB, respectively.

Figure 8 displays the time-wise difference of EHTC and hourly yield production from the HSS-SB\&IR, HSSZB\&IR and HSS-CB\&IR on 15-8-2020. The highest calculated EHTC of the HSS-SB\&IR, HSS-ZB\&IR and HSS-CB\&IR are $43.42,45.15$ and $47.02 \mathrm{~W} / \mathrm{m}^{2} \mathrm{~K}$ on 15-8-2020. The everyday average EHTC of 23.2, 24.94 and $26.58 \mathrm{~W} / \mathrm{m}^{2} \mathrm{~K}$ is calculated for the HSS-SB\&IR, HSS-ZB\&IR and HSS-CB\&IR, respectively. The everyday average EHTC of the HSS-CB\&IR is greater than the HSS-SB\&IR, HSS-ZB\&IR due to the greater thermal conductivity value of copper basin and IR. The everyday mean EHTC value of the HSS-ZB\&IR and HSS-CB\&IR is $7.5 \%$ and $14.5 \%$ higher as compared to the everyday average EHTC of the HSS-SB\&IR and 
every day average EHTC value of the HSS-CB\&IR is 6.5\% higher than the everyday mean EHTC value of the HSS-ZB\&IR. In HSS-CB\&IR, copper material and IR improves the Ts.w and so it has greater hourly and everyday EHTC than the HSS-ZB\&IR and HSS-SB\&IR. From figure 6, it is found that yield production from the HSS-SB\&IR, HSS-ZB\&IR and HSS-CB\&IR are increasing in the before noon and decreases in afternoon. The highest yield of $0.82,0.91$ and $0.97 \mathrm{~kg}$ was produced from the HSS-SB\&IR, HSS-ZB\&IR and HSSCB\&IR, respectively. The everyday yield production from the HSS-SB\&IR is $4.28 \mathrm{~kg}$, from the HSS-ZB\&IR is $5.04 \mathrm{~kg}$ and from the HSS-CB\&IR is $5.67 \mathrm{~kg}$ on 15-8-2020. While using the copper basin and IR in the HSS, yield was augmented by about $32.49 \%$ and $17.9 \%$ related to the HSS-SB\&IR, HSS-ZB\&IR, respectively.

In the HSS-CB and HSS-CB\&IR, due to copper properties and IR it stores the more heat energy in the basin and water. Also it decreases the heat losses from the HSS basin to the air so yield production from the HSS-CB is greater than the HSS-SB and HSS-ZB and yield production form the HSS-CB\&IR is greater than the HSS-SB\&IR and HSS-ZB\&IR.

\subsection{Time-wise variant of Thermal efficiency (TE) and Exergy efficiency (EE) of the HSS-SB, HSS-ZB, HSS- CB, HSS-SB\&IR, HSS-ZB\&IR and HSS-CB\&IR}

Time-wise variant of TE and EE of the HSS-SB, HSS-ZB and HSS-CB are shown in Figure 9. The TE of the HSS-SB, HSS-ZB and HSS-CB are rises in morning and got peak value at 14:00 and then it record low value till 19:00. The TE of the HSS-SB starts with $4.40 \%$ at $07: 00$, had a raising trend and got $55.61 \%$ at 14:00 and then it had a reducing trend till 19:00 (14.47\%). Also TE of the HSS-ZB starts at $5.12 \%$ at 07:00, had a rising trend and got $61.3 \%$ at $14: 00$ and then it had a reducing trend till 19:00 (22.72). Similarly the TE of the HSS-CB starts at $6.94 \%$ at $07: 00$, had a raising trend and got $65.91 \%$ at $14: 00$ and then it had a reducing trend till 19:00. The daily TE of the HSS-SB, HSS-ZB and HSS-CB are 25.14, 30.23 and $35.19 \%$ on 14-8-2020. The TE of the HSS-CB is 39.97 and $16.4 \%$ higher than TE of the HSS-SB and HSS-ZB. Similarly, the TE of the HSS-ZB is $20.26 \%$ higher than the TE of the HSS-SB. The use of copper basin in the HSS-CB enhances the water temperature, EHTC, yield and hence it had greater TE than the TE of the HSS-ZB and HSS-SB. The EE of the HSS-SB, HSS-ZB and HSS-CB are raises in morning and got peak value at 14:00 and then it decreases till 19:00. The EE of the HSS-SB starts at 0.03\% at 07:00, had a raising trend and got $3.75 \%$ at $14: 00$ and then it had a reducing trend till 19:00 (0.22). Also EE of the HSSZB starts with $0.06 \%$ at $07: 00$, had a raising trend and got $4.6 \%$ at $14: 00$ and then it had a reducing trend till $19: 00(0.48 \%)$. Similarly the EE of the HSS-CB starts with $0.07 \%$ at $07: 00$, had a raising trend and got $4.96 \%$ at $14: 00$ and then it had a reducing trend till 19:00 (0.94\%). The daily EE of the HSS-SB, HSS-ZB and HSS-CB are $1.26,1.62$ and $1.98 \%$ on $14-8-2020$. The EE of the HSS-CB is $56.87 \%$ and $21.88 \%$ higher than EE of the HSS-SB and HSS-ZB and EE of the HSS-CB is $16.4 \%$ higher than the HSS-ZB. The EE of the stills is maximum for the HSS-CB because EE directly related to yield and available solar intensity. For the period of noon hours, the difference between Ts.w and $\mathrm{Tg}$ is greater so at the time of noon hour EE is higher than the evening.

Time-wise variant of TE and EE of the HSS-SB\&IR, HSS-ZB\&IR and HSS-CB\&IR are shown in Figure 10. The TE of the HSS-SB\&IR, HSS-ZB\&IR and HSS-CB\&IR are rises in morning and reached peak value at 
14:00 and then it decreases till 19:00. The TE of the HSS-SB\&IR starts with 5.71\% at 07:00, had a raising trend and got $63.75 \%$ at $14: 00$ and then it had a reducing trend till 19:00 $(28.66 \%)$. Also TE of the HSSZB\&IR starts at $9.02 \%$ at $07: 00$, had a rising trend and reached $69.3 \%$ at $14: 00$ and then it had a reducing trend till 19:00 (29.96). Similarly the TE of the HSS-CB\&IR starts at $11.53 \%$ at $07: 00$, had a raising trend and reached $72.16 \%$ at $14: 00$ and then it had a reducing trend till 19:00. The daily TE of the HSS-SB\&IR, HSS-ZB\&IR and HSS-CB\&IR are $31.45,36.62$ and $41.12 \%$ on $15-8-2020$. The TE of the HSS-CB\&IR is 30.76 and $12.29 \%$ higher than TE of the HSS-SB\&IR and HSS-ZB\&IR. Similarly, the TE of the HSS-ZB\&IR is $16.45 \%$ higher than the TE of the HSS-SB\&IR. The use of copper basin and IR in the HSS enhances the water temperature, EHTC, yield and hence it had greater TE than the TE of the HSS-ZB\&IR and HSSSB\&IR. The EE of the HSS-SB\&IR, HSS-ZB\&IR and HSS-CB\&IR are raises in morning and reached peak value at 14:00 and then it decreases till 19:00. The EE of the HSS-SB\&IR starts at 0.05\% at 07:00, had a raising trend and got $4.28 \%$ at $14: 00$ and then it had a reducing trend till 19:00 (0.6\%). Also EE of the HSSZB\&IR starts with $0.08 \%$ at $07: 00$, had a raising trend and got $4.83 \%$ at $14: 00$ and then it had a reducing trend till 19:00 (0.72\%). Similarly the EE of the HSS-CB\&IR starts with $0.19 \%$ at $07: 00$, had a raising trend and got $5.21 \%$ at $14: 00$ and then it had a reducing trend till 19:00 (1.05\%). The daily EE of the HSS-SB\&IR, HSS-ZB\&IR and HSS-CB\&IR are $1.69,2.12$ and $2.51 \%$ on $15-8-2020$. The EE of the HSS-CB\&IR is $48.31 \%$ and $18.29 \%$ higher than EE of the HSS-SB\&IR and HSS-ZB\&IR. The EE of the HSS-ZB\&IR is $16.45 \%$ higher than the HSS-SB\&IR. The EE of the HSS is maximum for the HSS-CB\&IR because EE directly related to yield and input. For the period of noon hours, the difference between Ts.w and Tg is higher so at the time of noon hour $\mathrm{EE}$ is higher than the evening.

\section{Assessment Of Current Study With Available Related Works}

In Table 2 shows the comparison of our results with published similar works. From the Table 2, it can be noticed that the productivity of "V" type SS with mirror [31] is minimum with a value equal to $11.92 \%$. However, for the double SS with reflector, it is maximum with a value equal to $93.39 \%$ [32]. The present study produced maximum yield of $4.28,5.04$ and $5.67 \mathrm{~kg} / \mathrm{m}^{2}$ using HSS-SB\&IR, HSS-ZB\&IR and HSSCB\&IR, respectively. 
Table 2

Assessment of current study with available related works

\begin{tabular}{|c|c|c|c|}
\hline Author name & Type of SS & Enhancement techniques & $\begin{array}{l}\text { Productivity } \\
\text { improvement (\%) }\end{array}$ \\
\hline \multirow[t]{7}{*}{ Our results } & \multirow{7}{*}{$\begin{array}{l}\text { Hemispherical } \\
\text { SS }\end{array}$} & - Steel Basin & - \\
\hline & & - Zinc Basin & 17.03 \\
\hline & & - Copper Basin & 37.08 \\
\hline & & $\begin{array}{l}\text { - Steel Basin and Internal } \\
\text { Reflector }\end{array}$ & 17.58 \\
\hline & & - Zinc Basin and Internal & 38.46 \\
\hline & & Reflector & 55.77 \\
\hline & & $\begin{array}{l}\text { - Copper Basin and Internal } \\
\text { Reflector }\end{array}$ & \\
\hline \multirow[t]{2}{*}{ (Kumar et al. 2008) } & \multirow[t]{2}{*}{ "V" type SS } & - Mirror & 11.92 \\
\hline & & - Mirror and charcoal & 14.11 \\
\hline $\begin{array}{l}\text { (Gnanaraj et al. } \\
\text { 2019) }\end{array}$ & $\begin{array}{l}\text { Double slope } \\
\text { SS }\end{array}$ & - Reflector & 93.39 \\
\hline (Omara et al. 2013) & Stepped SS & - Internal reflectors & 75.00 \\
\hline \multirow{2}{*}{$\begin{array}{l}\text { (Abdullah et al. } \\
2020)\end{array}$} & \multirow[t]{2}{*}{ Trays SS } & - Internal reflectors & 58.00 \\
\hline & & - External reflectors & 75.00 \\
\hline \multirow{2}{*}{$\begin{array}{l}\text { (Chandrika et al. } \\
2021 \text { ) }\end{array}$} & \multirow{2}{*}{$\begin{array}{l}\text { Single slope } \\
\text { SS }\end{array}$} & - Reflective glass mirror & 68.57 \\
\hline & & - Reflective aluminum foil sheet & 48.57 \\
\hline
\end{tabular}

\section{Water Quality Analysis}

Table 3 depicts the properties of saline and distilled water. It is observed that $\mathrm{P}^{\mathrm{H}}$ value of saline water is 8.12 and distilled water is 7.12 which is within the consumable levels. After distillation, salt content (2.86 $\mathrm{g} / \mathrm{l})$ presents in the saline water was completely removed so that electrical conductivity of the distilled water was drastically decreased from 5300 to $28 \mu \mathrm{S} / \mathrm{cm}$ and TDS of the distilled water was drastically decreased from 7042 to $22 \mathrm{mg} / \mathrm{l}$. 
Table 3

water quality analysis

\begin{tabular}{|lll|}
\hline Properties & Saline water & Distilled water \\
\hline $\mathrm{pH}$ & 8.12 & 7.12 \\
\hline $\mathrm{EC}(\mathrm{\mu S} / \mathrm{cm})$ & 5300 & 28 \\
\hline $\mathrm{TDS}(\mathrm{mg} / \mathrm{l})$ & 7042 & 22 \\
\hline $\mathrm{TSS}(\mathrm{mg} / \mathrm{l})$ & 253 & 2 \\
\hline Salinity $(\mathrm{g} / \mathrm{l})$ & 2.86 & 0 \\
\hline $\mathrm{SO}_{4}{ }^{2-}(\mathrm{mg} / \mathrm{l})$ & 1033 & 5 \\
\hline $\mathrm{Cl}^{-(\mathrm{mg} / \mathrm{l})}$ & 905 & 9 \\
\hline $\mathrm{K}^{+}(\mathrm{mg} / \mathrm{l})$ & 23 & 0.25 \\
\hline $\mathrm{Na}^{+}(\mathrm{mg} / \mathrm{l})$ & 1280 & 2.2 \\
\hline $\mathrm{Mg}^{+}(\mathrm{mg} / \mathrm{l})$ & 182 & 0.82 \\
\hline $\mathrm{Ca}^{2+}(\mathrm{mg} / \mathrm{l})$ & 180 & 1.83 \\
\hline
\end{tabular}

\section{Economic Evaluation \\ 6.1 Daily yield}

Table 4 presents the daily yield of the HSS-SB, HSS-ZB, HSS-CB, HSS-SB\&IR, HSS-ZB\&IR and HSS-CB\&IR recorded during the $12 \mathrm{Hrs}$ of the day of the experiment on August 14 and 15, 2020. From these results, it is clear that the maximum value of the daily yield is obtained for the HSS-CB\&IR.

Table 4

Cumulative yield of HSS-SB, HSS-ZB, HSS-CB, HSS SB\&IR, HSS-ZB\&IR and HSS-CB\&IR.

\begin{tabular}{|lllllll|}
\hline & HSS-SB & HSS-ZB & HSS-CB & HSS-SB\&IR & HSS-ZB\&IR & HSS-CB\&IR \\
\hline Yield & 3.64 & 4.26 & 4.99 & 4.28 & 5.04 & 5.67 \\
$\left(\mathrm{~kg} / \mathrm{m}^{2}\right)$ & & & & & & \\
\hline EHTC & 21.49 & 23.44 & 24.82 & 23.20 & 24.94 & 26.58 \\
$\left(\mathrm{~W} / \mathrm{m}^{2}\right)$ & & & & & & \\
\hline TE $(\%)$ & 25.14 & 30.23 & 35.19 & 31.45 & 36.62 & 41.12 \\
\hline EE (\%) & 1.26 & 1.62 & 1.98 & 1.69 & 2.12 & 2.51 \\
\hline
\end{tabular}




\subsection{Economic Evaluation}

In Table 5, the recovery period of HSS-SB, HSS-ZB, HSS-CB, HSS-SB\&IR, HSS-ZB\&IR and HSS-CB\&IR is summarized. The payback period of HSS-SB is 43 days, HSS-ZB is 38 days and HSS-CB is 33 days. The amount invested is returned in the case of the HSS-SB\&IR is 37 days, HSS-ZB\&IR is 32 days and HSSCB\&IR is 29 days.

Table 5

Fabrication cost of the HSS-SB, HSS-ZB, HSS-CB, HSS-SB\&IR, HSS-ZB\&IR and HSS-CB\&IR. $(1 \$=132.78$ DZD, $1 €=156.03$ DZD)

\begin{tabular}{|lllllll|}
\hline & $\begin{array}{l}\text { HSS- } \\
\text { SB }\end{array}$ & $\begin{array}{l}\text { ZSS- } \\
\text { ZB }\end{array}$ & $\begin{array}{l}\text { HSS- } \\
\text { CB }\end{array}$ & $\begin{array}{l}\text { HSS- } \\
\text { SB\&IR }\end{array}$ & $\begin{array}{l}\text { HSS- } \\
\text { ZB\&IR }\end{array}$ & $\begin{array}{l}\text { HSS- } \\
\text { CB\&IR }\end{array}$ \\
\hline Total cost of manufacture (DZD) & 9000 & 9000 & 9000 & 9050 & 9050 & 9050 \\
\hline The price of metal tray & 300 & 600 & 900 & 300 & 600 & 900 \\
\hline Maintenance cost (DZD) & 50 & 50 & 50 & 60 & 60 & 60 \\
\hline Total cost (DZD) & 9350 & 9650 & 9950 & 9410 & 9710 & 10010 \\
\hline $\begin{array}{l}\text { The amount of water produced during the } \\
\text { day ((kg/m²/day) }\end{array}$ & 3.64 & 4.26 & 4.99 & 4.28 & 5.04 & 5.67 \\
\hline $\begin{array}{l}\text { cost per liter of distilled water on the market } \\
\text { (DZD) }\end{array}$ & 60 & 60 & 60 & 60 & 60 & 60 \\
\hline $\begin{array}{l}\text { The price of daily water production (DZD) } \\
\text { Recovery period (Days) }\end{array}$ & 218.4 & 255.6 & 299.4 & 256.8 & 302.4 & 340.2 \\
\hline
\end{tabular}

\section{Conclusions}

This work highlights the positive effect of an IR on the performance of HSS with various basin materials. This simple technique includes a reflective aluminum foil sheets on the inner walls of the HSS with various basin materials (steel, zinc and copper). The conclusions are as follows:

- Using the reflective aluminum foil sheets and high thermal conductivity metal basins (copper) enhances the efficiency of HSS. Aluminum foil sheets increase the reflection of the solar radiation inside the basin, and the trays increase the absorption of solar radiation resulting increases in temperature of the brine water.

- The distilled water production from the HSS-SB, HSS-ZB and HSS-CB are 3.64, 4.26 and 4.99 $\mathrm{kg} / \mathrm{m}^{2}$.

- The distilled water production from the HSS-SB\&IR during the day is equal to $4.28 \mathrm{~kg} / \mathrm{m}^{2}$. However, it is equal to $5.04 \mathrm{~kg} / \mathrm{m}^{2}$ from the HSS-ZB\&IR and it is equal to $5.67 \mathrm{~kg} / \mathrm{m}^{2}$ from the HSS-CB\&IR.

- The daily accumulation of HSS was improved by 17.03 and $37.08 \%$ by using the zinc and copper basin as compared to the HSS-SB. 
- The daily yield was improved by $17.58,38.46$ and $55.77 \%$ by using the steel, zinc and copper basin and reflective aluminum foil sheets as compared to the HSS-SB.

- The invested amount is recovered from a HSS-SB, HSS-ZB, HSS-CB, HSS-SB\&IR, HSS-ZB\&IR and HSS-CB\&IR are 43, 38, 33, 37, 32 and 29 days.

- The productivity of the distillate with the copper basin and reflective aluminum foil sheets is much better than other solar stills.

Reflective aluminum foil sheets and high thermal conductivity metal trays greatly improve the yield of the solar distillation and increases the yield and efficiency.

\section{Abbreviations}

\begin{tabular}{ll} 
SS & Solar Still \\
\hline IR & Internal Reflector \\
\hline HSS-SB & Hemispherical Solar Still with Steel Basin \\
\hline HSS-ZB & Hemispherical Solar Still with Zinc Basin \\
\hline HSS-CB & Hemispherical Solar Still with Copper Basin \\
\hline HSS-SB\&IR & Hemispherical Solar Still with Steel Basin and Internal Reflector \\
\hline HSS-ZB\&IR & Hemispherical Solar Still with Zinc Basin and Internal Reflector \\
\hline HSS-CB\&IR & Hemispherical Solar Still with Copper Basin and Internal Reflector
\end{tabular}

\section{Declarations}

\section{Ethical Approval}

Not Applicable

\section{Consent to Participate}

Not Applicable

\section{Consent to Publish}

Not Applicable

\section{Funding}

There is no funding received for the research work carried out. 
The authors declare that there is no competing interest

\section{Availability of data and materials}

Not Applicable

\section{Authors Contribution}

Mohammed El Hadi Attia - Project administration, Writing original manuscript \& Software

Ahmed Kadhim Hussein - review \& editing

Prabha Ramadoss - Formal analysis, review \& editing

Sivakumar Vaithilingam - Writing original manuscript, review \& editing

Asif Afzal - review \& editing

Obai Younis - review \& editing

\section{References}

Abdullah AS, Younes MM, Omara ZM, Essa FA (2020) New design of trays solar still with enhanced evaporation methods-Comprehensive study. Solar Energy 203:164-174.

Al-Madhhachi H, Smaisim G (2021) Experimental and numerical investigations with environmental impacts of affordable square pyramid solar still. Solar Energy 216:303-314.

Alnaimat F, Ziauddin M, Mathew B (2021) A review of recent advances in humidification and dehumidification desalination technologies using solar energy. Desalination 499:114860.

Arunkumar T, Denkenberger D, Ahsan A, Jayaprakash R (2013) The augmentation of distillate yield by using concentrator coupled solar still with phase change material. Desalination 314:189-192.

Arunkumar T, Jayaprakash R, Denkenberger D, Ahsan A, Okundamiya M, Kumar S, Tanaka H, Aybar H (2012) An experimental study on a hemispherical solar still. Desalination 286:342-348.

Attia M, Driss Z, Kabeel A, Abdelgaied M, Manokar A, Sathyamurthy R, Hussein AK (2021) Performance evaluation of modified solar still using Aluminum foil sheet as absorber cover - a comparative study. Journal of Testing and Evaluation 49(5) https://doi.org/10.1520/JTE20200249.

Attia M, Kabeel A, Abdelgaied M, El-Maghlany W, Bellila A (2021) Comparative study of hemispherical solar distillers iron-fins. Journal of Cleaner Production 292:126071.

Attia M, Kabeel A, Abdelgaied M, Essa F, Omara Z (2021) Enhancement of hemispherical solar still productivity using iron, zinc and copper trays. Solar Energy 216:295-302. 
Benabderrahmane A, Benazza A, Hussein, AK (2020) Heat transfer enhancement analysis of tube receiver for parabolic trough solar collector with central corrugated insert. J Heat Trans-T ASME 142:062001-1 - 062001-8. https://doi.org/10.1115/1.4046440

Chandrika VS, Attia MEH, Manokar AM, Marquez FPG, Driss Z, Sathyamurthy R (2021) Performance enhancements of conventional solar still using reflective aluminium foil sheet and reflective glass mirrors: energy and exergy analysis. Environ Sci Pollut Res Int. doi: 10.1007/s11356-021-13087-2.

Chauhan V, Shukla S, Tirkey J, Rathore P (2021) A comprehensive review of direct solar desalination techniques and its advancements, Journal of Cleaner Production 284:124719.

Essa FA, Abdullah A, Omara Z, Kabeel A, Gamiel Y (2021) Experimental study on the performance of trays solar still with cracks and reflectors. Applied Thermal Engineering 188:116652.

Ghodbane M, Boumeddane B, Hussein, AK (2021) Performance analysis of a solar-driven ejector air conditioning system under EL-OUED climatic conditions, Algeria. J Therm Eng 7(1):172-189.

Gnanaraj S, Joe Patrick, Velmurugan V (2019) An experimental study on the efficacy of modifications in enhancing the performance of single basin double slope solar still. Desalination 467:12-28.

Hussein AK (2015) Applications of nanotechnology in renewable energies-A comprehensive overview and understanding. Renew Sust Energ Rev 42:460-476. https://doi.org/10.1016/j.rser.2014.10.027

Hussein AK, Kolsi L, Younis O, Li D, Ali H, Afrand M (2020) Using of nanotechnology concept to enhance the performance of solar stills - recent advances and overview. Journal of Engineering Science and Technology 15(6):3991-4031.

Hussein AK, Walunj A, Kolsi L (2016) Applications of nanotechnology to enhance the performance of the direct absorption solar collectors. J Therm Eng 2(1):529-540.

Ismail B (2009) Design and performance of a transportable hemispherical solar still. Renewable Energy $34: 145-150$.

Jobrane M, Kopmeier A, Kahn A, Cauchie H, Kharroubi A, Penny C (2021) Internal and external improvements of wick type solar stills in different configurations for drinking water production - a review. Groundwater for Sustainable Development 12:100519.

Kabeel A, El-Agouz S (2011) Review of researches and developments on solar stills. Desalination 276:112. https://doi.org/10.1016/j.desal.2011.03.042

Khadim M, Al-Wahid W, Hachim D, Sopian K (2021) Experimental study of the performance of cylindrical solar still with a hemispherical dome. Smart Science https://doi.org/10.1080/23080477.2021.1876298. 
Kumar B, Sanjay K, Jayaprakash R (2008) Performance analysis of a V-type solar still using a charcoal absorber and a boosting mirror. Desalination 229:217-230.

Kumar B, Selva Sanjay Kumar, Jayaprakash R (2008) Performance analysis of a "V" type solar still using a charcoal absorber and a boosting mirror. Desalination 229(1-3):217-230.

Mandi B, Menni Y, Ameur H (2021) Energy analysis of the performance of a hybrid solar still composed of a parabolic concentrator with PV generator. SN Applied Sciences $3 \mathrm{https}: / /$ doi.org/10.1007/s42452-02104258-4.

Minasian A, Al-Karaghouli A (1994) An improved solar still: the wick-basin type, Energy Conversion and Management 36:213-217.

Navale V, Kumbhar S, Bhojawani V (2016) Experimental study of masonic solar still by using nanofluid. International Engineering Research Journal Special Issue:984-987.

Omara ZM, Kabeel AE, Younes MM (2013) Enhancing the stepped solar still performance using internal reflectors. Desalination 314:67-72.

Omara Z, Kabeel AE, Younes M (2014) Enhancing the stepped solar still performance using internal and external reflectors. Energy Conversion and Management 78:876-881.

Pandey G (1984) Effect of dried and forced air bubbling on the partial pressure of water vapour and performance of solar still. Solar Energy 33:13-18.

Rahbar N, Esfahani J (2012) Experimental study of a novel portable solar still by utilizing the heat pipe and thermoelectric module. Desalination 284:55-61.

Rahbar N, Esfahani J, Fotouhi-Bafghi E (2015) Estimation of convective heat transfer coefficient and water-productivity in a tubular solar still - CFD simulation and theoretical analysis. Solar Energy 113:313323.

Raju J, Vaibhav T, Chaitanya, C, Kotebavi V (2017) An experimental investigation on hemispherical basin solar still coupled with heat pipes, evacuated tubes and paraboloid concentrator. IOP Conference Series (ICMAEM-2017): Materials Science and Engineering 225:012056.

Rostami S, Sepehrirad M, Dezfulizadeh A, Hussein AK, Goldanlou A, Shadloo M (2020) Exergy optimization of a solar collector in flat plate shape equipped with elliptical pipes filled with turbulent nanofluid flow: a study for thermal management. Water 12(8):2294- 2310.

https://doi.org/10.3390/w12082294

Sakthivel M, Shanmugasundaram S, Alwarsamy T (2010) An experimental study on regenerative solar still with energy storage medium-Jute cloth. Desalination 264:24-31. 
Taheri P, Zahedi A (2020) Techno-economic analysis of a renewable quadruple hybrid system for efficient water / biofuel production. Solar Energy 211:1053-1069.

\section{Figures}

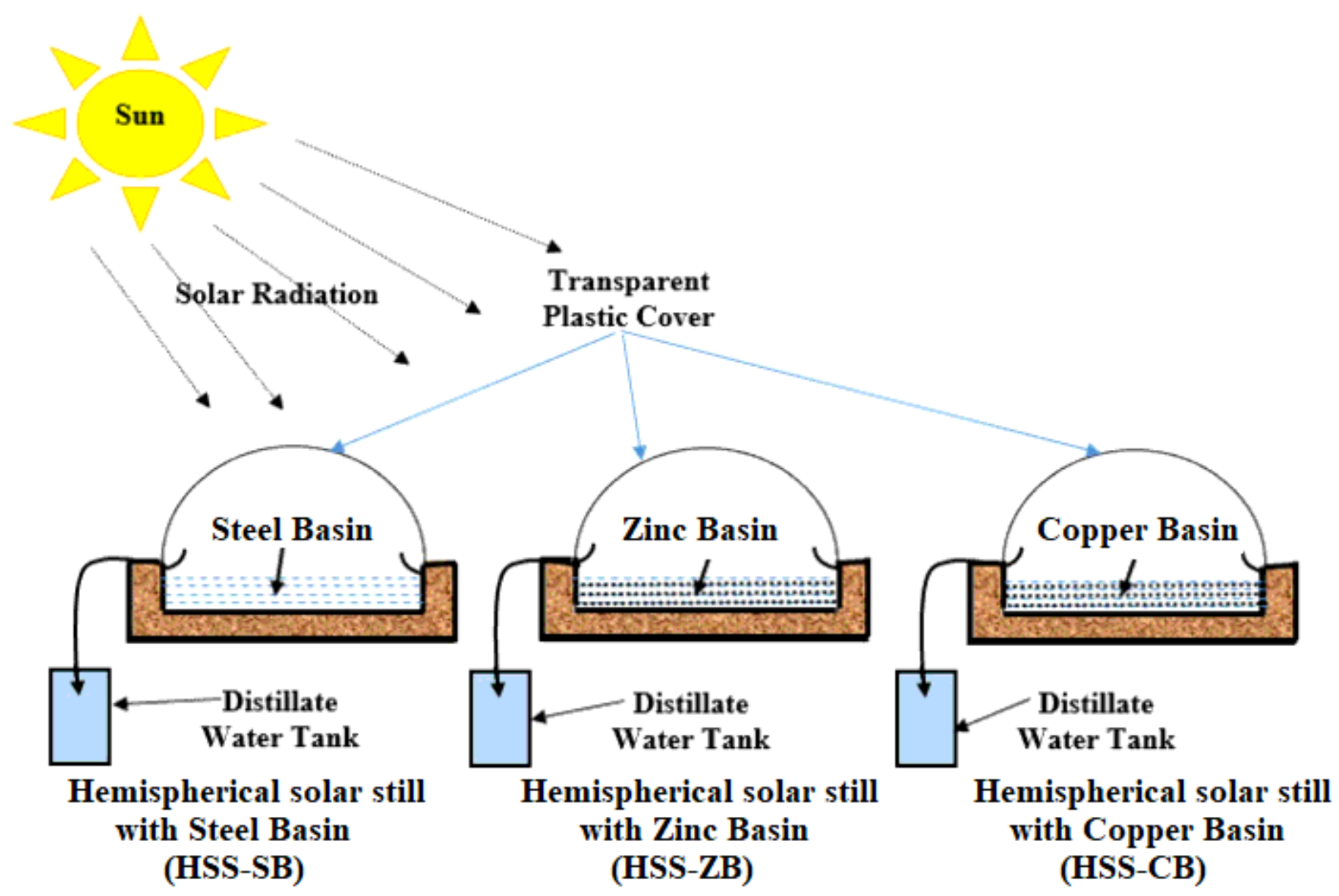

Figure 1

Schematic of the HSS 


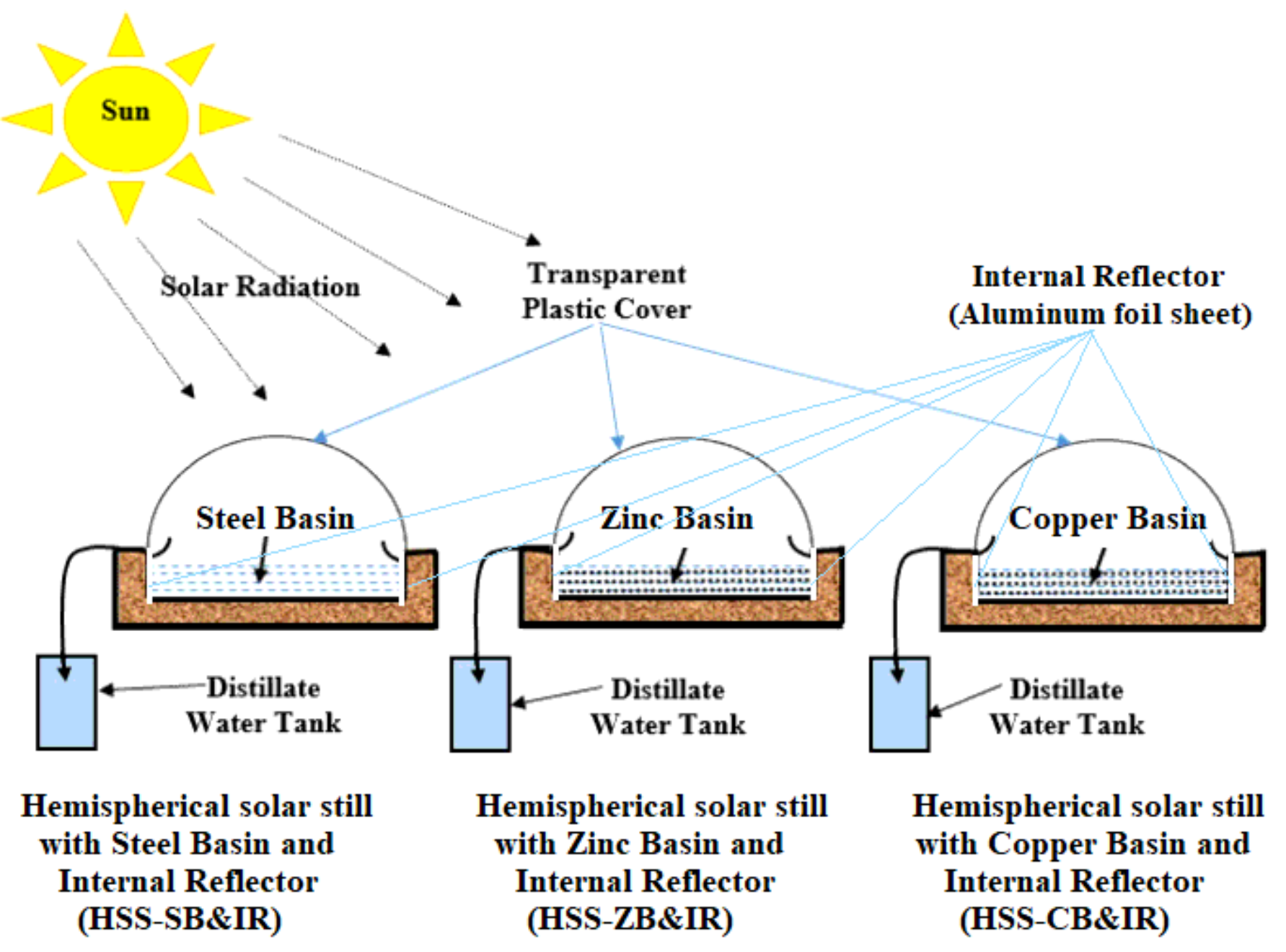

Figure 2

Layout of the three HSS utilized in the experimental test rig for the second test case 


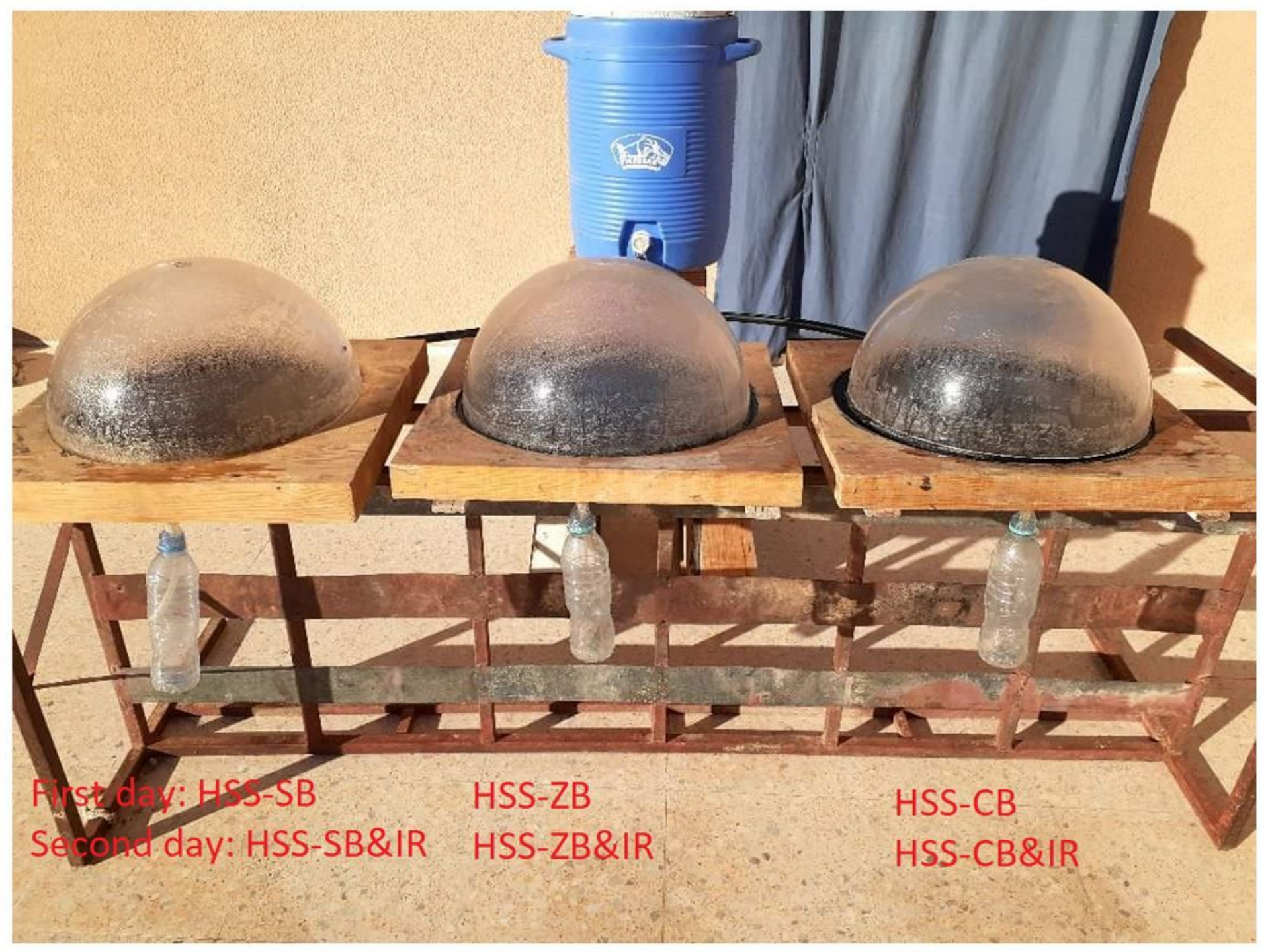

Figure 3

Photographic view of experimental test rig 


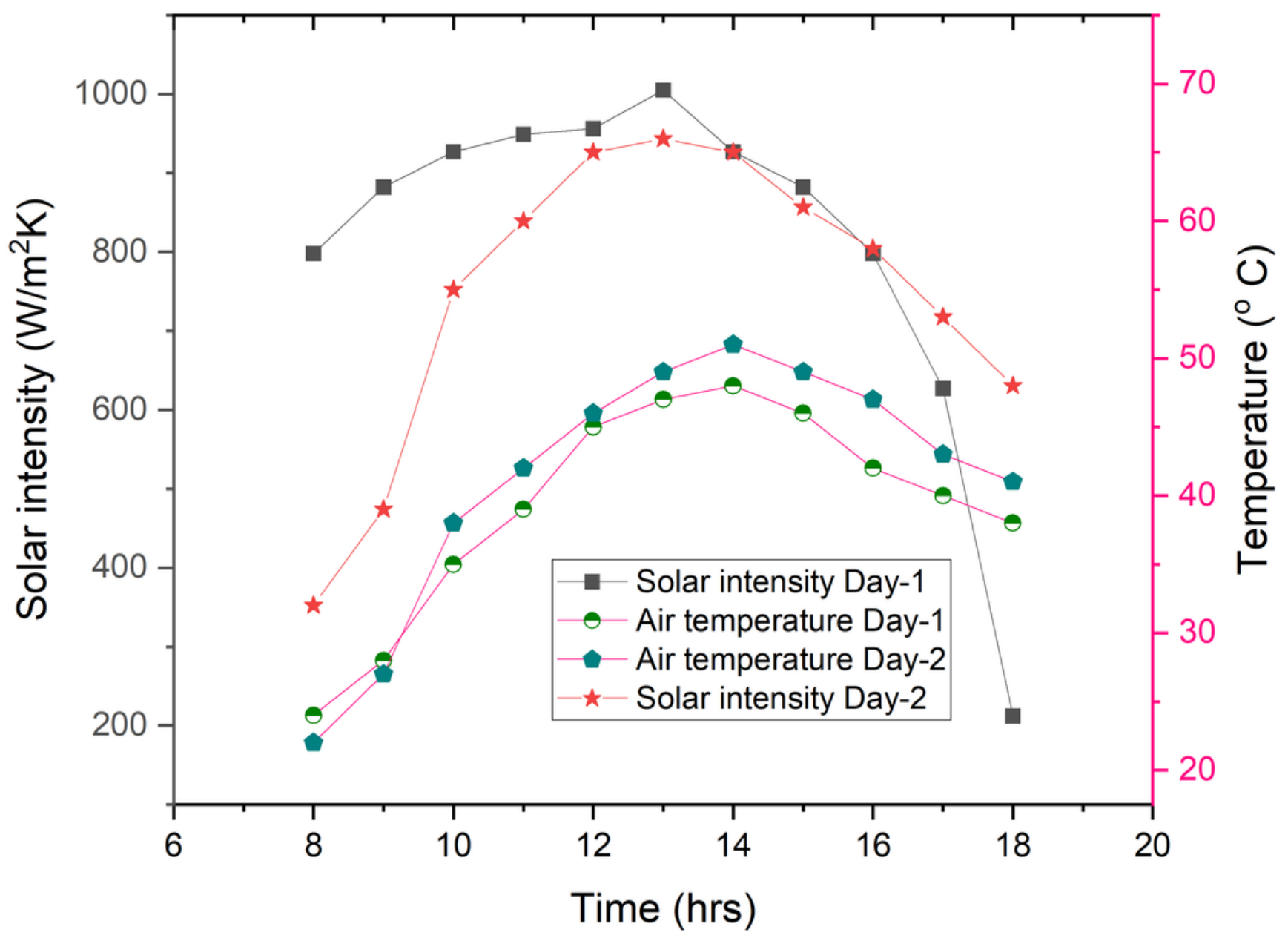

Figure 4

Time-wise variant of $\mathrm{I}(\mathrm{t})$ and $\mathrm{Ta}$ 


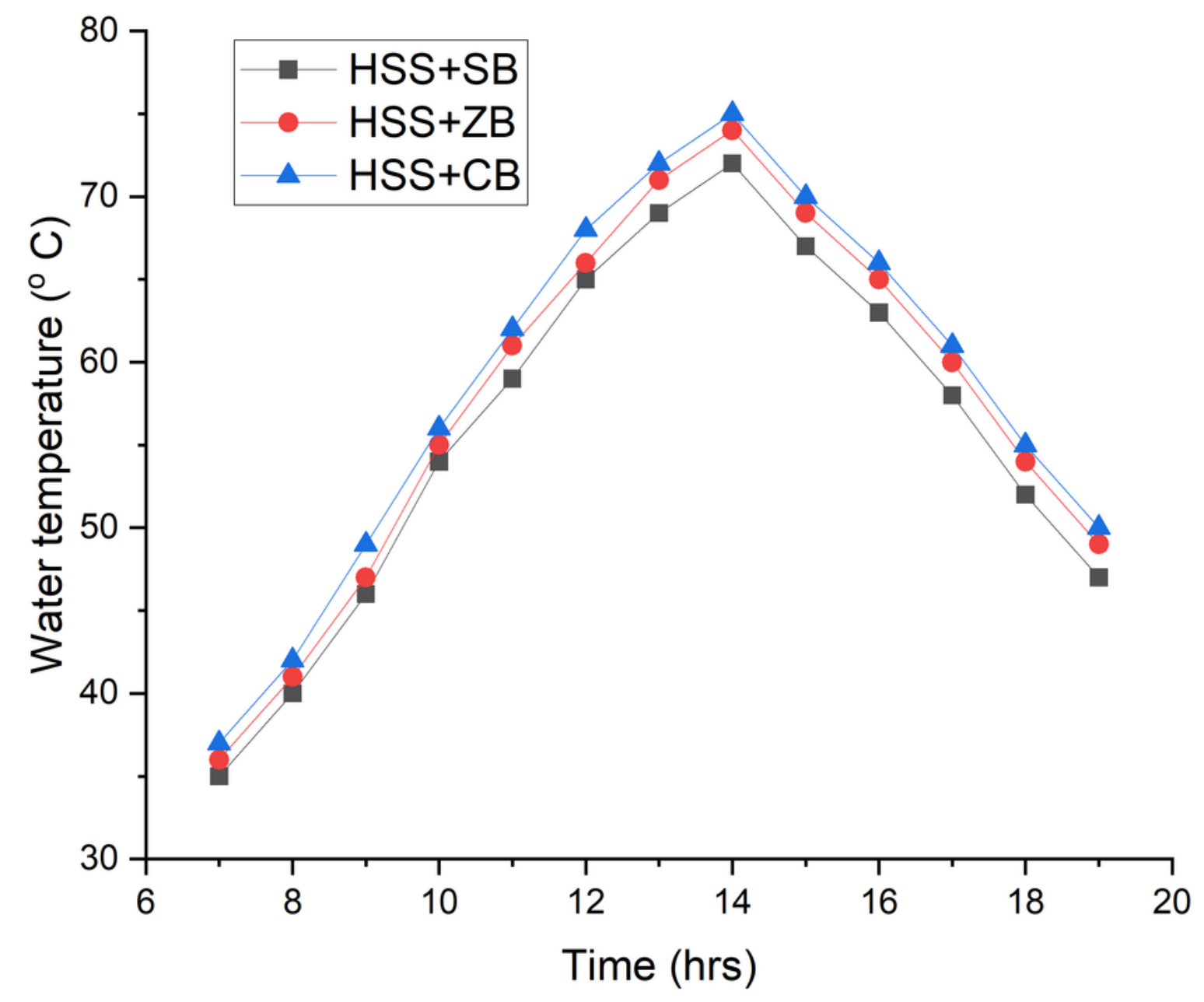

Figure 5

Time-wise variant of Ts.w for the HSS-SB, HSS-ZB and HSS-CB 


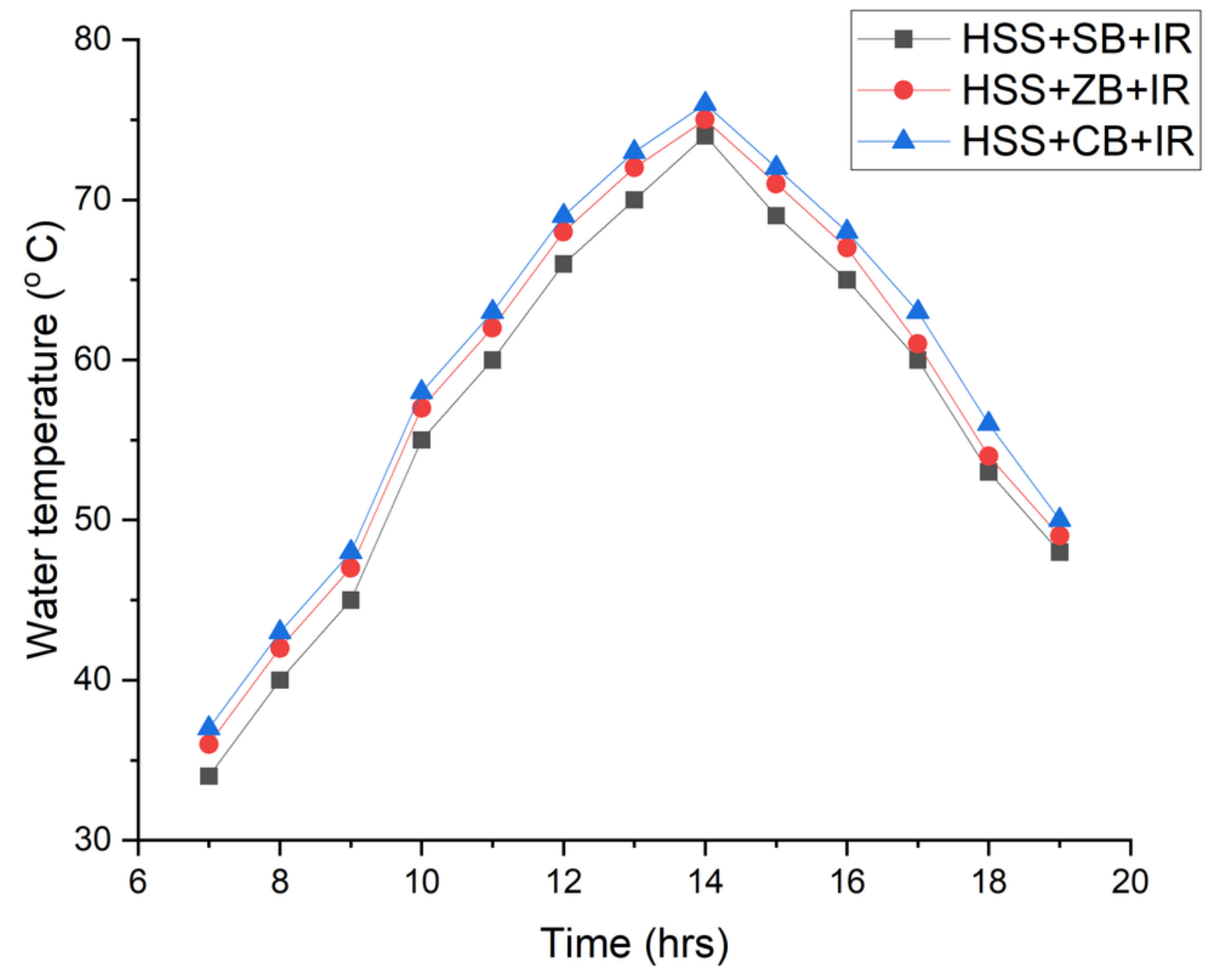

Figure 6

Time-wise variant of Ts.w for the HSS-SB\&IR, HSS-ZB\&IR and HSS-CB\&IR 


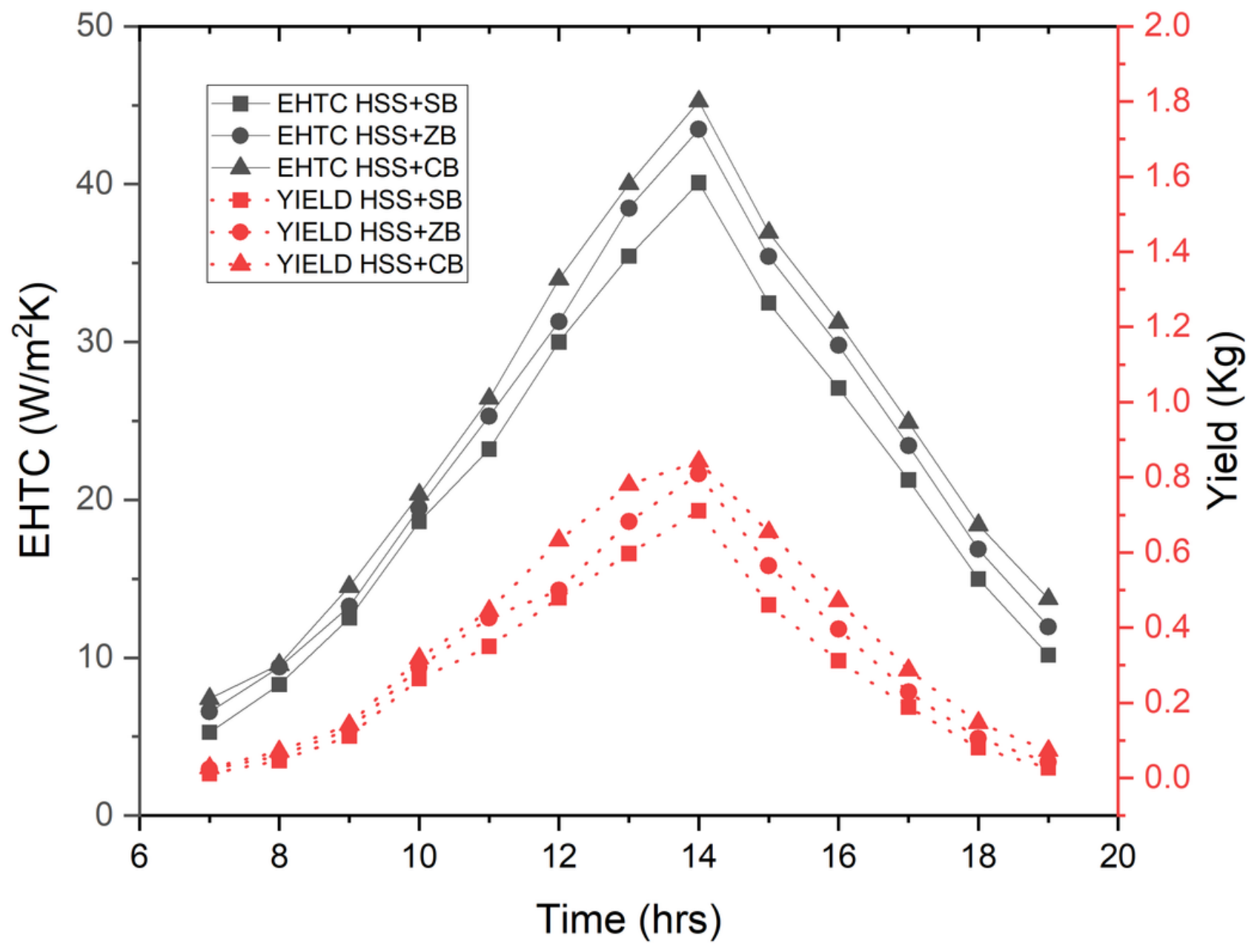

Figure 7

Time-wise variant of EHTC and yield production from the HSS-SB, HSS-ZB and HSS-CB on 14-8-2020 


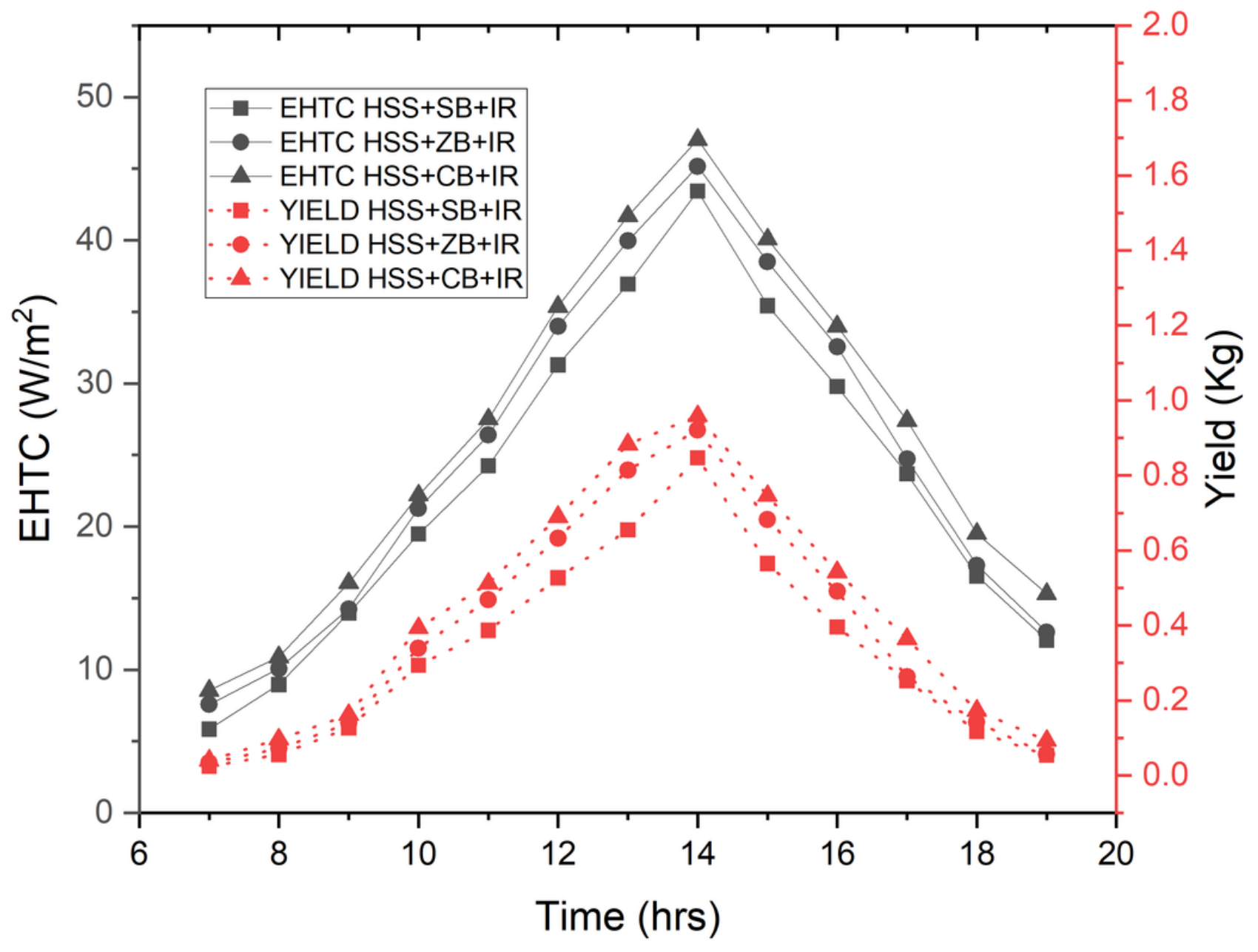

Figure 8

Time-wise variant of EHTC and yield production from the HSS-SB\&IR, HSS-ZB\&IR and HSS-CB\&IR on 15$8-2020$ 


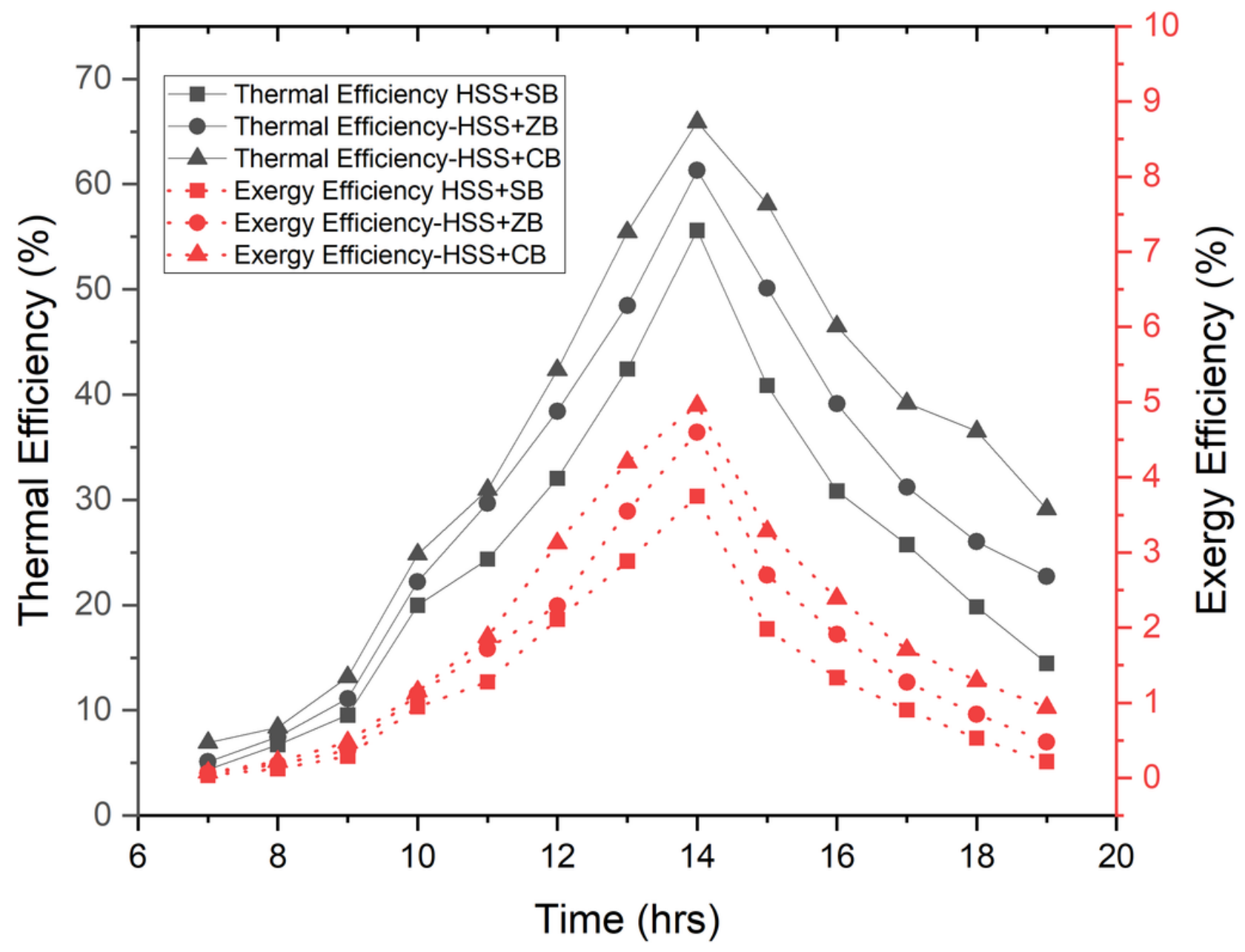

Figure 9

Time-wise difference of TE and EE of the HSS-SB, HSS-ZB and HSS-CB on 14-8-2020 


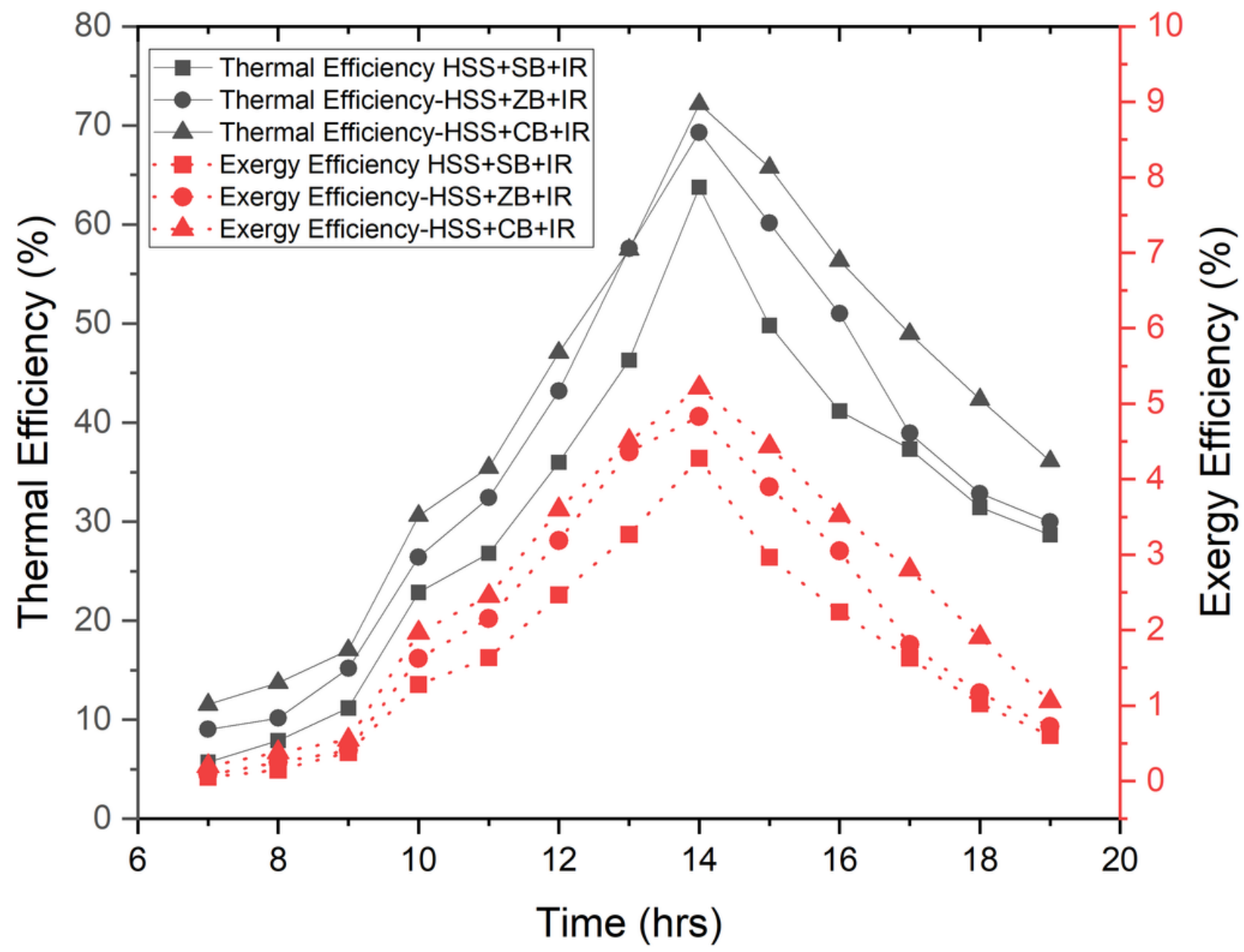

Figure 10

Time-wise difference of TE and EE of the HSS-SB\&IR, HSS-ZB\&IR and HSS-CB\&IR on 15-8-2020 